\title{
BEHAVIORAL INTENTION ANALYSIS ON PET CARING IN JAKARTA
}

\author{
Ujang Sumarwan ${ }^{* 1}$, Tiara Putri Sajuthi**), and Netti Tinaprilla***) \\ *) Department of Family and Consumer Sciences, Faculty of Human Ecologi, Bogor Agricultural University \\ Jl. Lingkar Akademik, Campus IPB Dramaga, Bogor 16680 \\ **) 24 Hours Veterinary Clinic Drh (Vet) Cucu Kartini and Associate \\ Jl Sunter Permai Raya, Ruko Nirwana Sunter Asri III, J1 No 2, Jakarta 14350 \\ ${ }^{* * *}$ Department of Agribusiness, Faculty of Economics and Management, Bogor Agricultural University \\ Jl. Agatis, Campus IPB Dramaga, Bogor 16680
}

\begin{abstract}
The aim of the study was to explain the relationship between attitudes and interests in caring for pets. The theoretical basis of this research is Theory of Planned Behavior (TPB). This study used a survey and sampling method conducted at several animal clinics in Jakarta. The number of samples obtained in this study amounted to 178 respondents selected by convenience sampling method using questionnaires and direct interviews. Data analysis using SEM method. The results showed that the attitude toward behavior and perceived behavior control had a significant effect on the behavior intention. This indicates that the more profits a pet owner earned in maintaining an animal, the more it will encourage interest in caring for pets better. The managerial implications for animal care product and service providers are to create a variety of products and develop a business for animal health care and services.
\end{abstract}

Keywords: pets, attitude, behavior intention, theory of planned behavior

\begin{abstract}
Abstrak: Tujuan dari penelitian adalah menjelaskan hubungan antara sikap dan minat memelihara hewan peliharaan. Landasan teori pada penelitian ini adalah Theory of Planned Behavior (TPB). Penelitian ini menggunakan metode survei dan pengambilan contoh dilakukan pada beberapa klinik hewan di Jakarta. Jumlah sample yang diperoleh pada penelitian ini berjumlah 178 responden yang dipilih dengan metode convenience sampling menggunakan kuesioner dan wawancara langsung. Analisis data dengan menggunakan metode SEM. Hasil penelitian menunjukkan bahwa attitude toward behavior dan perceived behavior control berpengaruh signifikan terhadap behavior intention. Hal ini menandakan bahwa semakin banyak manfaat yang diperoleh seorang pemilik hewan saat memelihara seekor hewan, maka semakin mendorong minat untuk merawat hewan peliharaan dengan lebih baik. Implikasi manajerial bagi penyedia produk dan jasa perawatan hewan adalah menciptakan variasi produk dan melakukan pengembangan bisnis usaha jasa pelayanan perawatan dan kesehatan hewan.
\end{abstract}

Kata kunci: hewan peliharaan, sikap, behavior intention, theory of planned behavior

\footnotetext{
${ }^{1}$ Corresponding author:

Email: sumarwan@apps.ipb.ac.id
} 


\section{INTRODUCTION}

Owning pets has become a trend for various countries. Baquero and Chiozzotto (2015) conducted a research through a field survey in the city of Sao Paolo Brazil. The results showed that out of 450 households visited randomly, $56 \%$ had dogs and/or cats with a density of $951 \mathrm{dogs} / \mathrm{km} 2$ and $195 \mathrm{cats} / \mathrm{km} 2$. Based on the trends that occur in the city of Sao Paolo, it is possible that this trend also occurs in Jakarta. One of the factors that drives a person to own a pet is the satisfaction or benefits felt by pet owners when they have pets.

According to Hermanto (2014), there are many positive benefits of caring for pets, including reducing stress and boredom. A research on reducing stress levels by having a pet has been reviewed by Cline (2010); Lustig and Cramer (2015). Cline (2010) examined the psychological factors of someone who has a pet. The results showed that maintaining dogs could reduce a person's depression level, especially in single women, while a research conducted by Lustig and Cramer (2015) stated that caring for animals could reduce stress levels of the owner.

Everyone who keeps animals also has their own way of caring for their animals. This is mainly influenced by the behavior of pet owners. Consumer behavior is a process that underlies a person to purchase, search, choose, use, and evaluate products and services aiming to meet needs or desires. According to Sumarwan (2015), consumer behavior can be interpreted as all activities, actions, and psychological processes that encourage someone to take action before buying a product, when buying, when using a product, when spending a product, and evaluating a product. According to Blackwell et al
(2012), many factors influence consumer behavior, one of which is the individual differences. The individual differences consist of consumer resources, motivation and involvement, knowledge, attitude, personality and lifestyle. This research highlights more on the consumer behavior of pet owners.

According to Fishbein and Ajzen (2010), attitudes may result from behavior, yet attitudes are not the same as behavior. Between attitude and behavior, there is one psychological factor that must exist to make them consistent; i.e. intention. The intention to behave is influenced by three components, namely attitude, subjective norms, and perceived behavioral control. The three components are contained in the theory of planned behavior or TPB, which is a frame of mind that can explain the determinants of certain behaviors. For more details, the basic framework of TPB can be seen in Figure 1

The measurement of attitude by using TPB was carried out by Truong (2009) and Suryandari et al. (2016) with PLS analysis, and Lee et al. (2010) and Suprapti (2013) with multiple regression analysis. Meanwhile, the analysis in this research was conducted by the SEM method. TPB analysis by using the SEM method was reviewed by Annilda et al. (2017). According to Sarwono (2016), Structural Equation Model (SEM) is a statistical modeling technique that is very crosssectional, linear and general. SEM includes factor analysis, path analysis, and regression. In general, the SEM method focuses more on abstract psychological variables, such as "intelligence" or "attitude". An example of a SEM model for measuring attitudes based on the theory of planned behavior can be seen in Figure 2.

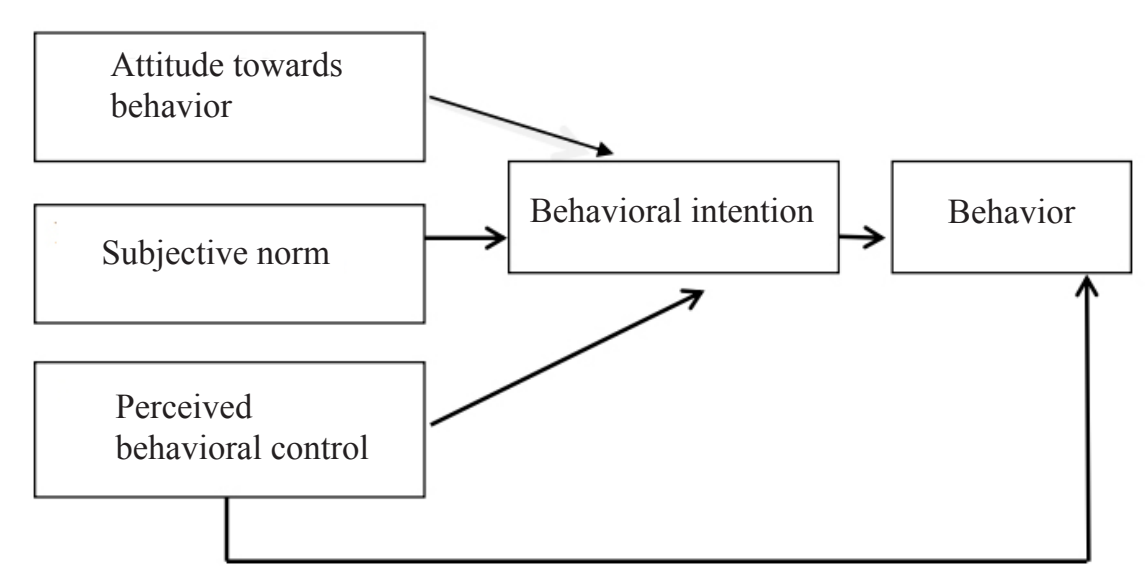

Figure 1. Theory of planned behavior 


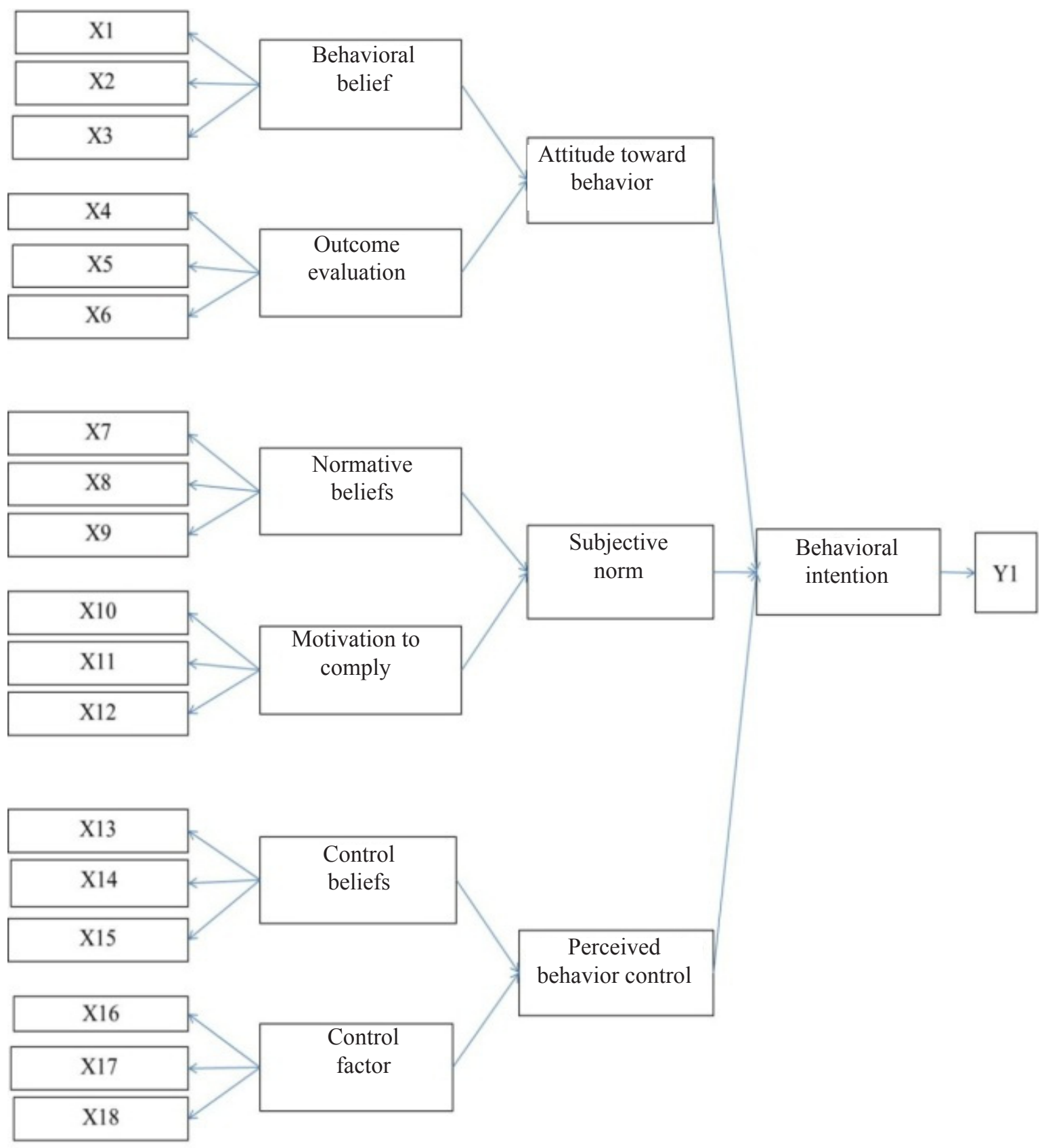

Figure 2. SEM Model

Many factors becomes the reasons and motivations for someone to keep animals. These reasons were stated in the study conducted by Belk (1996); Davis (2008). Belk (1996) conducted a research through interviews and observations in America and stated that the motive of pet owners to care for animals is as a hobby (pleasure), a part of themselves, family members, and toys. Meanwhile, Davis (2008) revealed that the main motivation for someone to keep a pet is to meet social and psychological needs. By caring for animals, someone will feel like they have friends; in addition, pet owners can also join animal lover communities to make it easier to interact with many people who have the same passion.
Animal care is certainly not an easy thing, for they must be willing to spend time, money, and energy to care for their animals. Kanimozhi \& Sumadevi (2014) conducted research on pet care in one area in India in which the results showed that care and concern for pets is currently increasing, especially in densely populated urban areas. Pet owners, especially in urban areas, are willing to pay higher costs to meet their animal care needs, whereas Lee \& Kok (2015) conducted a research in Malaysia through in-depth interviews with six respondents with a duration of around 1-1.5 hours/respondent. The average results of the interview concluded that dog owners who are very fond of their dogs consider their dogs are like themselves. Pet 
owners are willing to spend large amount of money to buy feed, pay veterinary fees, and buy supplements and other products.

Based on the data from the American Veterinary Medical Association - AVMA (2012) and the American Humane Association - AHA (2012), 62\% (72.9 million households) of Americans have pets. Dogs and cats dominate pets in America. The number of dogs is 37$46 \%$ and the number of cats is $30-39 \%$. Caring for dogs and cats is certainly costly. Daneshvary and Schwer (1990) stating that there are significant differences between dog and cat owners in spending money to meet the needs of animals, especially in health care products, conducted research on the costs of dog and cat care. Cat owners are quite sensitive to prices, while dog owners are not.

Servicesforpetsincludemedicalservices(veterinarians), animal care (pet boarding or pet hotels), salons and training (especially for dogs), while for product needs generally include food (pet food), cages and accessories (chains, clothes, etc.). According to Chen et al. (2012), the trend of caring for animals has been going on for a long time in the United States and the number is increasing annually. According to the data obtained, the products and services for pets in 2010 have increased 10 times more than in the 1990s. Based on the trends that occur in America, it is possible that Indonesia also experiences the same trend. In connection with this, a research of consumer behavior is needed for the intention in caring for pets. Therefore, this research aims to examine the analysis of intention in caring for pets on three factors that shape these intention including attitudes toward behavior, subjective norms and control of perceived behavior.

\section{METHODS}

The research design utilized in this research was survey methods. Data retrieval was conducted at several animal clinics in Jakarta area. The duration of this research was three months from July to September 2017. The sampling technique of this research was convenience sampling. The respondents as the objects of this research were pet owners who own at least one dog and/or cat for more than three months. The number of samples obtained in this study was 178 .
Data collection technique used in this research was structured questionnaire. Questionnaires were directly given face to face. Some questions were made based on Likert scale with five variations of answers starting from strongly disagree to strongly agree.

The theory used in this research was Theory of Planned Behavior (TPB). The TPB model consists of six exogenous latent variables and one endogenous latent variable. Exogenous latent variables consist of behavioral beliefs, outcome evaluations, normative beliefs, motivation to comply, belief control and control factor, while one endogenous latent variable is the behavior intention. The data were analyzed by using Microsoft Excel and SEM (Structural Equation Modeling) methods.

Furthermore, the research framework can be seen in Figure 3, with the hypothesis used in this study:

H1 : ATB (attitude toward behavior) has a significant correlation to the intention in caring for pets

$\mathrm{H} 2$ : SN (subjective norm) has a significant correlation to the intention in caring for pets

H3 : PBC (perceived behavioral control) has a significant correlation to the intention in caring for pets

\section{RESULTS}

\section{Profile of Respondents}

Respondents of pet owners live in Jakarta, most of them are in North Jakarta, with the average of being women, married, Chinese, and mature. The main job is entrepreneurship and has monthly expenses of 5-10 million. The distribution of respondents in Table 1.

\section{Analysis of Theory of Plan Behavior (TPB) by using Structural Equation Modelling (SEM)}

TPB analysis consists of six aspects, and each aspect consists of three attributes; therefore, 18 attributes were obtained. Eighteen attributes acted as independent variables, while the independent variable was behavioral intention (Y). Attribute variables in Table 2. 


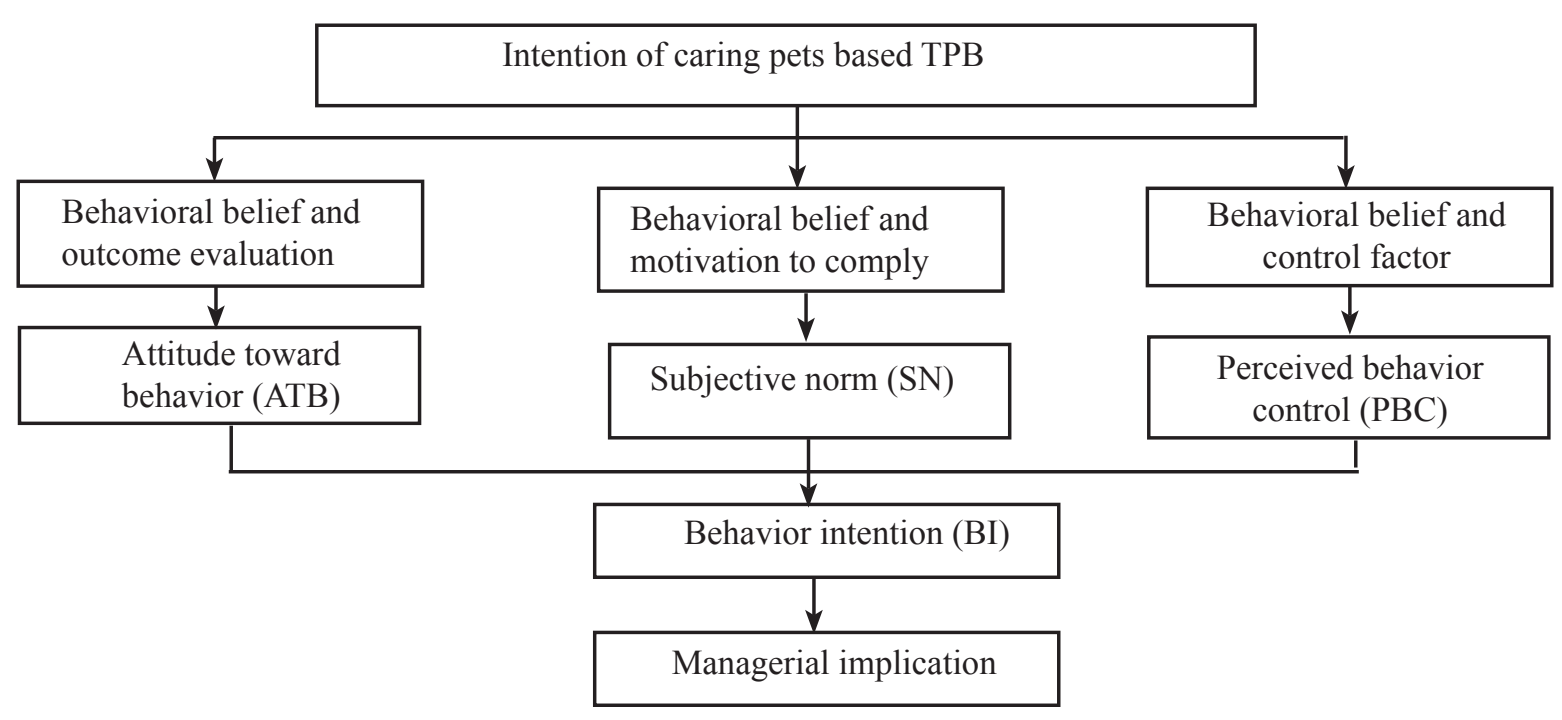

Figure 3. Research framework

Table 1. Characteristics of respondents

\begin{tabular}{lcc}
\hline \multicolumn{1}{c}{ Respondents } & & $\%$ \\
\hline Domicile & & \\
Central Jakarta & 17 & $10 \%$ \\
West Jakarta & 41 & $23 \%$ \\
North Jakarta & 43 & $24 \%$ \\
South Jakarta & 23 & $13 \%$ \\
East Jakarta & 17 & $10 \%$ \\
Others & 37 & $20 \%$ \\
Total & 178 & $100 \%$ \\
Age & & \\
$<25$ & 21 & $12 \%$ \\
$25-35$ & 58 & $33 \%$ \\
$36-45$ & 43 & $24 \%$ \\
46 - 55 & 38 & $21 \%$ \\
$>55$ & 18 & $10 \%$ \\
Total & 178 & $100 \%$ \\
Sex & & \\
Male & 38 & $21 \%$ \\
Female & 140 & $79 \%$ \\
Total & 178 & $100 \%$ \\
Tribe/Ethnicity & & \\
Javanese & 34 & $19 \%$ \\
Sundanese & 13 & $7 \%$ \\
Batak & 4 & $2 \%$ \\
Chinese & 114 & $64 \%$ \\
Others & 13 & $7 \%$ \\
Total & 178 & $100 \%$ \\
\hline & &
\end{tabular}

\begin{tabular}{lcc}
\hline \multicolumn{1}{c}{ Respondents } & & $\%$ \\
\hline Marital Status & & \\
Single & 70 & $39 \%$ \\
Married & 103 & $58 \%$ \\
Widowed/Divorced & 5 & $3 \%$ \\
Total & 178 & $100 \%$ \\
Educational Status & & \\
Senior High School (SMA) & 24 & $13 \%$ \\
Undergraduate (S1) & 120 & $67 \%$ \\
Postgraduate (S2) & 28 & $16 \%$ \\
Others & 6 & $3 \%$ \\
Total & 178 & $100 \%$ \\
Occupation & & \\
Student & 9 & $5 \%$ \\
Employee & 52 & $29 \%$ \\
Civil Servant & 3 & $2 \%$ \\
Entrepreneur & 63 & $35 \%$ \\
Housewife & 39 & $22 \%$ \\
Others & 12 & $7 \%$ \\
Total & 178 & $100 \%$ \\
Monthly Expense & & \\
$<5$ millions & 47 & $26 \%$ \\
5 - 10 millions & 63 & $35 \%$ \\
$10-25$ millions & 51 & $29 \%$ \\
25 - 50 millions & 15 & $8 \%$ \\
$>$ 50 millions & 2 & $1 \%$ \\
Total & 178 & $100 \%$ \\
\hline
\end{tabular}


Table 2. Variables influencing the intention in caring for pets

\begin{tabular}{|c|c|c|c|}
\hline Construct & Aspect & Attribute & Symbol \\
\hline \multirow[t]{6}{*}{ Attitude Toward Behavior } & \multirow[t]{3}{*}{ Behavioral Beliefs } & Stress Relief & $\mathrm{X} 1$ \\
\hline & & Personal Satisfaction & $\mathrm{X} 2$ \\
\hline & & Good Deeds & $\mathrm{X} 3$ \\
\hline & \multirow[t]{3}{*}{ Outcome Evaluation } & The importance of stress relief & $\mathrm{X} 4$ \\
\hline & & The importance of personal satisfaction & $\mathrm{X} 5$ \\
\hline & & The importance of good deeds & $\mathrm{X} 6$ \\
\hline \multirow[t]{6}{*}{ Subjective Norm } & \multirow[t]{3}{*}{ Normative Beliefs } & Veterinary & $\mathrm{X} 7$ \\
\hline & & Friend & $\mathrm{X} 8$ \\
\hline & & Family Member & X9 \\
\hline & \multirow[t]{3}{*}{ Motivation to Comply } & Veterinary & $\mathrm{X} 10$ \\
\hline & & Friend & $\mathrm{X} 11$ \\
\hline & & Family Member & $\mathrm{X} 12$ \\
\hline \multirow[t]{6}{*}{ Perceived Behavior Control } & \multirow[t]{3}{*}{ Control Beliefs } & Time to raise pets & $\mathrm{X} 13$ \\
\hline & & Fund to raise pets & $\mathrm{X} 14$ \\
\hline & & Adequate Facilities & $\mathrm{X} 15$ \\
\hline & \multirow[t]{3}{*}{ Power of Control Factor } & Lacking of Time & $\mathrm{X} 16$ \\
\hline & & Limited Funds & $\mathrm{X} 17$ \\
\hline & & Facility Fulfilment & $\mathrm{X} 18$ \\
\hline Behavioral Intention & & Overall intention in caring for pets & $\mathrm{Y} 1$ \\
\hline
\end{tabular}

Based on the results of the validity test, there are variables with loading value below 0.5 and $t$-value below 1.96. According to Wijanto (2008), t-value below 1.96 indicates that the loading factor is not significant, while the value of loading factor below 0.5 can be eliminated because it is not in accordance with the standards. Therefore, indicator variables, X5.3 and X6.3 can be excluded from the model and obtained Standardized loading factor re-specification, which can be seen in Figure 4. T-value is re-specified in Figure 5 and loading factor values and t-count measurement model is re-specified in Table 3.

According to Wijanto (2008), the suitability criteria of the measurement model were measured based on the validity of the indicator variable on its latent variables. According to Igbaria et al. (1997), an indicator variable is considered valid when it has a standardized loading factor more than the tolerable loading factor limit of 0.50 , and has a t-value above 1.96. Based on the results of the standardized loading factor and t-values diagram, it can be seen that all variables met the validity requirements indicated by the standardized value of a loading factor of more than 0.5 and the $t$-value above 1.96 (significant).

\section{Overall Model Fit}

The criteria of overall model fit utilized in this research are the parameters of Room Mean Square Residual (RMR), Room Mean Square Error of Approximation (RMSEA), Goodness of Fit (GFI), Adjustment Goodness of Fit Index (AGFI), Normed Fit Index (NFI), Comparative Fit Index (CFI), and Relative Fit Index (RFI).

Based on the results of the suitability criteria, the RMSEA criterion produced a value of $0.067 \leq 0.08$, which means that the resulting model is in good fit. The use of other goodness of fit criteria, including CFI, NFI, GFI, AGFI, and RFI, produced a value of $\geq$ 0.90 , which means that the resulting model is in good fit. Likewise, another goodness of fit measurement criteria, RMR, produced a value of $\leq 0.1$, which means the model is also in good fit. Assessment of good fit for all criteria indicates that the overall model made can explain empirical information in accordance with the data collected, so that the hypothetical testing can be conducted. 


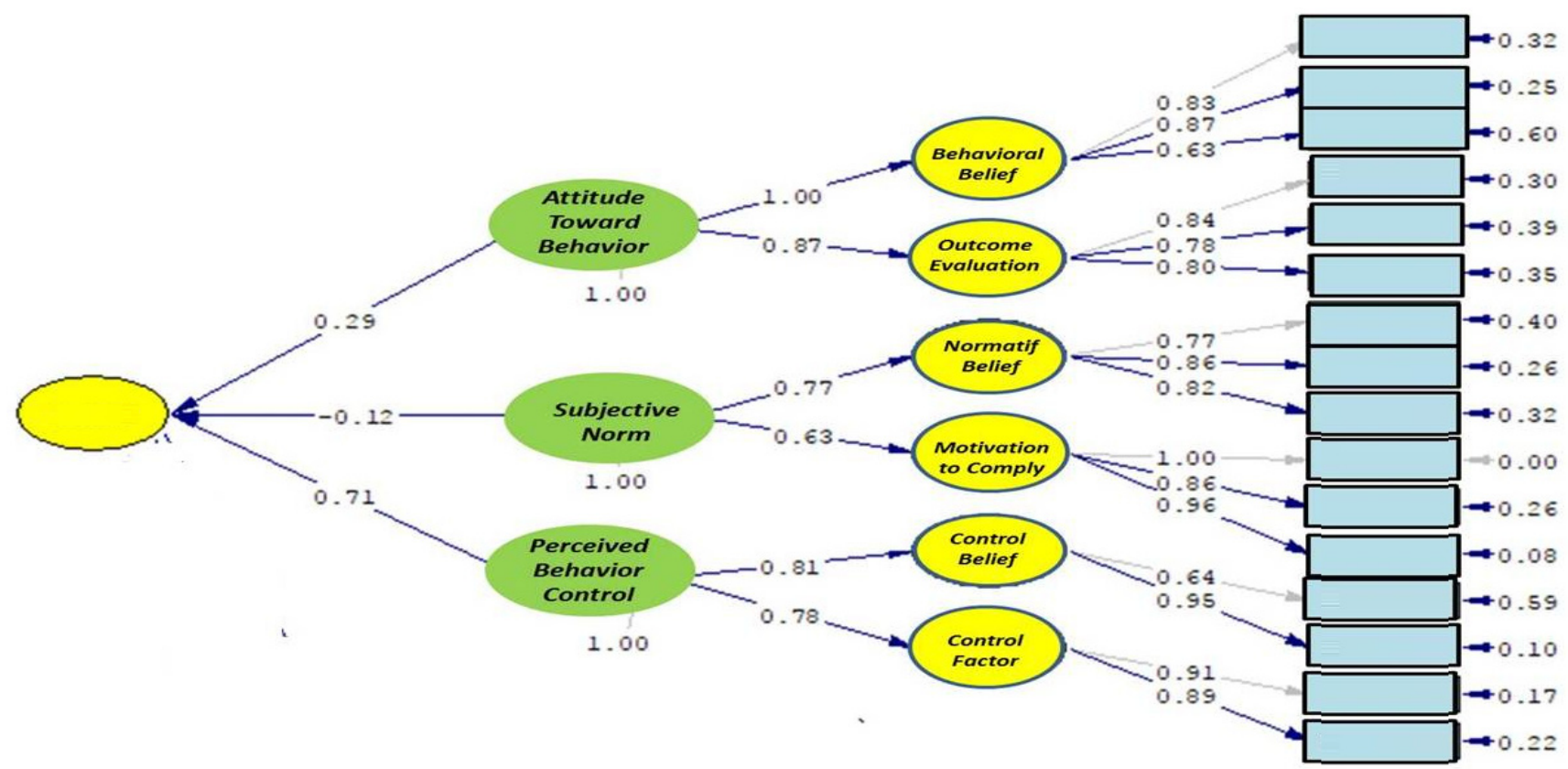

Figure 4. Re-specification of standardized loading factor

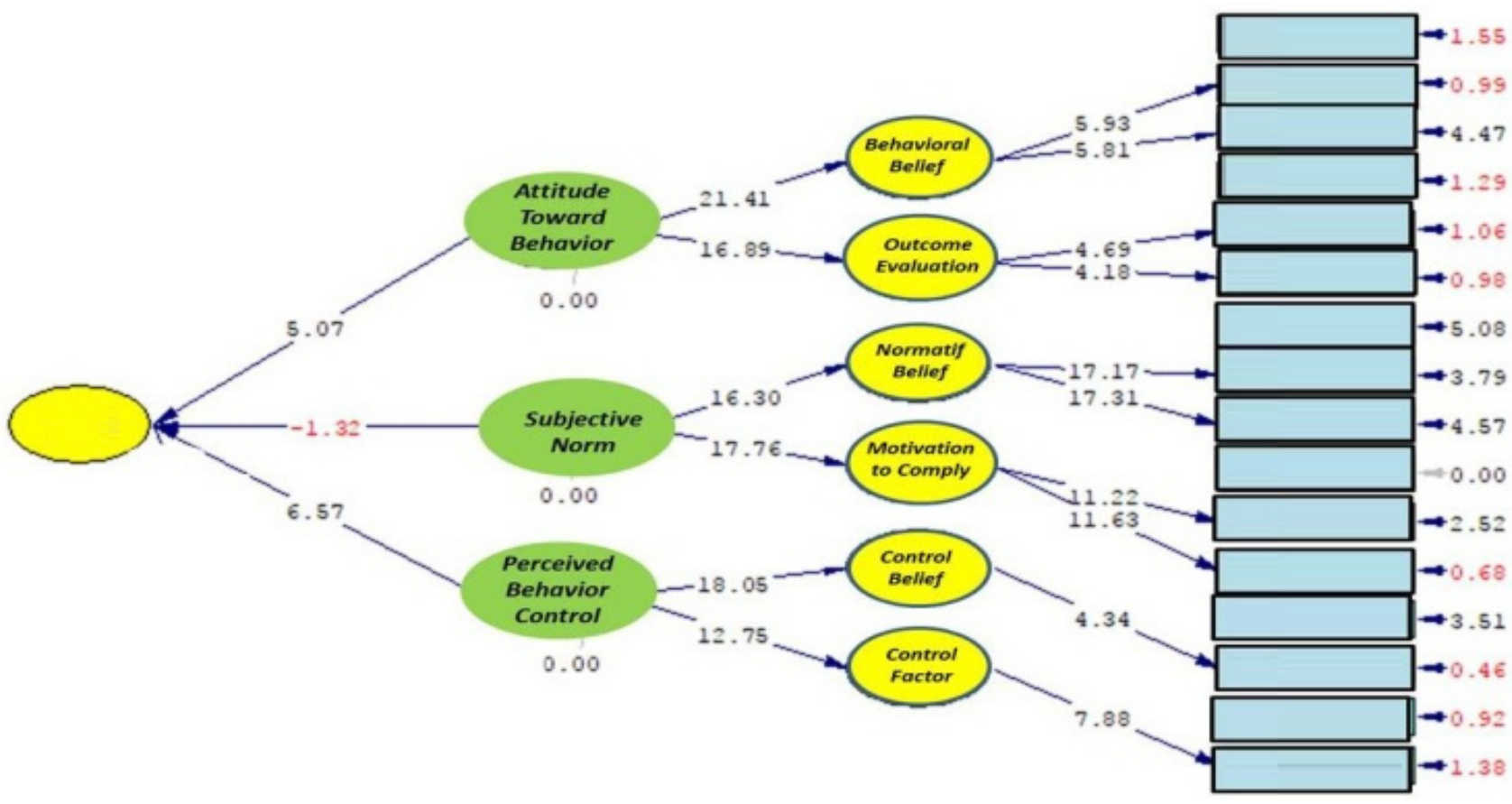

Figure 5. Re-specification of T Value 
Table 3. The value of loading factor and T-Count measurement re-specification model

\begin{tabular}{lcccc}
\hline Latent Variable & Indicator Variable & Loading Factor & t-count & Note \\
\hline BB & X1.1 & 0.83 & & Valid \\
& X1.2 & 0.87 & 5.93 & Valid \\
XE & X1.3 & 0.63 & 5.81 & Valid \\
& X2.1 & 0.84 & 4.69 & Valid \\
& X2.2 & 0.78 & 4.18 & Valid \\
X2.3 & 0.80 & & Valid \\
NB & X3.1 & 0.77 & 17.17 & Valid \\
& X3.2 & 0.86 & 17.31 & Valid \\
& X3.3 & 0.82 & & Valid \\
MC & X4.1 & 1.00 & 11.22 & Valid \\
& X4.2 & 0.86 & 11.63 & Valid \\
& X4.3 & 0.96 & & Valid \\
CB & X5.1 & 0.64 & 4.34 & Valid \\
& X5.2 & 0.95 & & Valid \\
CF & X6.1 & 0.91 & 7.88 & Valid \\
& X6.2 & 0.89 & 21.41 & Valid \\
ATB & BB & 1.00 & 16.89 & Valid \\
& OE & 0.87 & 16.3 & Valid \\
SN & NB & 0.77 & 17.76 & Valid \\
& MC & 0.63 & 18.05 & Valid \\
PBC & CB & 0.81 & 12.75 & Valid \\
& CF & 0.78 & &
\end{tabular}

The Relationship of Attitude toward Behavior (ATB), Subjective Norms (SN) and Perceived Behavioral Control (PBC) with Behavior Intention (BI)

The test results showed that attitudes toward behavior (ATB) and behavioral control beliefs (PBC) had a significant relationship to the intention of caring for pets (BI). Meanwhile, subjective norms (SN) do not have a significant relationship to interest (BI). Variables of intention in caring for pets and loading factor values can be seen in Table 4 .

ATB construct is a factor that encourages a person to care for a pet. It consists of two aspects; i.e. Behavioral Belief and Outcome Evaluation. The biggest loading factor in forming ATB is BB with a loading factor of 1.00. This figure shows that the variable trust in animal care is a cognitive component that determines the attitude of consumers in caring for animals. This can be interpreted that the more positive the emphasis on the benefits of having a pet, the more it will encourage the intension in caring for pets.
$\mathrm{PBC}$ constructs are limiting factors that are presumed to inhibit or reduce intention in caring for pets. The PBC construct consists of two aspects; i.e. control belief and the power of control factors. The biggest loading factor in forming PBC is CB with a value of loading factor by 0.81 . This shows that there are inhibiting factors in caring for pets. The main factors that can be obstacles include limited funds and lacking of free time. Nevertheless, based on the results of the research, it shows that income and lacking of free time are not barriers for respondents to care for their pets.

\section{Managerial Implications}

Based on the results of SEM analysis, ATB and PBC have a significant effect on the intention in caring for pets. The managerial implications that can be proposed are as follow: Many benefits obtained by pet owners in caring for animals. The higher the benefits felt by pet owners, the more intention to care for animals will be. Animal care in general includes primary needs (feed), secondary needs (cages, accessories, etc.), and veterinarian costs. The managerial implication 
proposed is to vary products and services for animal care. Product variations can be in the form of variations in feed types and innovative and interesting accessories for the needs of animals (e.g. making pet collars, clothes, etc.) Limited funds are not considered obstacles for pet owners to care for their animals. Hence, the managerial implication that can be proposed is to develop a service business for the animal care needs. Service businesses that can be developed in animal care include animal salons, pet taxis, and pet clinics.

Table 4. Behavior Intention in caring for pets and the value of loading factor

\begin{tabular}{lccc}
\hline $\begin{array}{c}\text { Behavior Intention } \\
\text { (BI) }\end{array}$ & $\begin{array}{c}\text { Loading } \\
\text { factor }\end{array}$ & $\mid$-count $\mid$ & Conclusion \\
\hline $\begin{array}{l}\text { Attitude toward } \\
\text { behavior (ATB) }\end{array}$ & 0.29 & 5.07 & Significant \\
$\begin{array}{l}\text { Subjective Norm } \\
\text { (SN) }\end{array}$ & -0.12 & 1.32 & Insignificant \\
$\begin{array}{l}\text { Perceived Behavioral } \\
\text { Control (PBC) }\end{array}$ & 0.71 & 6.57 & Significant \\
\hline
\end{tabular}

\section{CONCLUSIONS AND RECOMMENDATIONS}

\section{Conclusions}

Based on the theory of planned behavior analyzed using SEM, it was found that the first relationship between ATB (Attitude toward Behavior) and interest (Intention) in caring for pets is significant. This indicates that the more positive the emphasis on the benefits of having a pet, the greater the interest in caring for pets. The second relationship between PCB (Perceived Behavioral Control) and interest (Intention) in caring for pets is also significant. This indicates that income and lacking of free time are not considered obstacles for respondents to care for their animals. The last relationship between SN (Subjective Norm) and interest (Intention) in caring for pets is not significant. This indicates that motivation from oneself and others does not affect the interest in caring for pets.

\section{Recommendations}

This research was conducted as an initial research for the development of further research. This research only discusses consumer behavior in terms of behavior towards the intention in caring for pets. Further research can discuss consumer behavior from the standpoint of lifestyle, motivation, and personality. In addition, this research only focused on Jakarta area; therefore, further research on the consumer behavior of pet owners in Indonesia as a whole can be interesting to discuss.

\section{REFERENCES}

Annilda F, Sumarwan U, Nugrahani E. 2018. Behavioral intention analysis on internet banking usage at bank xyz Bogor. Indonesian Journal of Business and Enterpreneurship 4(1): 64-74. http://dx.doi. org/10.17358/ijbe.4.1.64.

[AHA] American Humane Association. 2012. U.S. Pet (dog and cat) Population Fact Sheet. http:// www.bradfordlicensing.com/documents/petsfact-sheet.pdf [2017 Februari 28].

[AVMA] American Veterinary Medical Association. 2012. U.S. Petownership statistics. https:// www.avma.org/KB/Resources/Statistics/Pages/ Market-research-statistics-US-pet-ownership. aspx [2017 February 28].

Baquero OS, Chiozzotto EN. 2015. Demographic characteristics of owned dogs and cats of Votorantim, Sao Paulo State, Brazil. Journal Ciencia Rural Santa Maria 45(11): 2039-2043. https://doi.org/10.1590/0103-8478cr20141646.

Belk RW. 1996. Metaphoric relationship with pet. Journal Society and Animals 4(2): 121-145. https://doi.org/10.1163/156853096X00115.

Blackwell RD, Miniard PW, Engel JF.2012. Consumer Behavior. Singapore: Cengage Learning Asia Pte Ltd.

Chen A, Kuang PH, Peng N. 2012. A cluster analysis examination of pet owners' consumption value and behavior - segmenting owners strategically. Journal of Targeting, Measurment and Analysis for Marketing 20(2): 117-132. https://doi. org/10.1057/jt.2012.10.

Cline KMC. 2010. Psychological effects of dog ownership: role strain, role enhancement, and depression. The Journal of Social Psychology 150(2): 117-131. https://doi. org/10.1080/00224540903368533.

Daneshvary N, Schwer RK. 1990. The nature of demand for companion pet health care. Journal of Applied Business Research 9(4): 24-32. https://doi.org/10.19030/jabr.v9i4.5986.

Davis SLC. 2008. Motivation for petownership and its relevance to behavior problem. CompendiumVet. http://assets.prod.vetlearn.com.s3.amazonaws. com/mmah/66/040826e58c4dd5af3e7bb9e1f7bf 
48/filePV_30_08_423.pdf [2017 February 4].

Fishbein M, Ajzen I. 2010. Predicting and Changing Behavior: The Reasoned Action Approach. New York: Psychology Press (Taylor \& Francis).

Hermanto Y. 2014. Manfaat dari Memelihara Hewan Peliharaan. https://keluarga.com/1533/manfaatdari-memelihara-hewan-peliharaan[2017 February 28].

Igbaria M, Zinatelli N, Cragg P, Cavaye LM. 1997. Personal computing acceptance factors in small firms: a structural equation model. Journal MIS Quarterly 21(3): 279-302. https://doi. org/10.2307/249498.

Kanimozhi RS, Sumadevi. 2014. Customers purchase behavior towards pet retailing business in coimbatore district. Indian Journal of Applied Research 4(10): 352-355.

Lee HC, Kok HY. 2015. Self extension and purchase behavior of dog related products and services: an in-depth interview among selected malaysian dog owners. Asian Social Science 11(3): 26-36.

Lee J, Cerreto FA, Lee J. 2010. Theory of planned behavior and teachers' decisions regarding use of educational technology. Journal Educational Technology dan Society 13(1): 152-164.
Lustig KA, Cramer KM. 2015. Characteristic of pet owners: motivation and need fulfillment. Journal of Motivation, Emotion and Personality 2015(4): $45-52$.

Sarwono J. 2016. Teori SEM (Structural Equation Model). http://www.jonathansarwono.info/sem/ sem.htm [2016 November 19].

Sumarwan U. 2015. Perilaku Konsumen: Teori dan Penerapannya dalam Pemasaran. Jakarta: Ghalia Indonesia.

Suprapti NWS. 2010. Perilaku Konsumen: Pemahaman Dasar dan Aplikasinya Dalam Strategi Pemasaran. Bali: Udayana University Press.

Suryandari NKD, Suprapti NWS, Sukaatmadja IPG.2016. Aplikasi Theory of Planned Behavior dalam menjelaskan perilaku ekologis generasi Y di Kota Denpasar. Jurnal Manajemen, Strategi Bisnis dan Kewirausahaan 10(1): 31-41.

Truong Y. 2009. An evaluation of the Theory of Planned Behaviour in consumer acceptance of online video and television services. Electronic Journal Information Systems Evaluation 12(2): 177-186 Wijanto SH. 2008. Structural Equation Modelling. Yogyakarta: Graha Ilmu. 